\title{
Damropa (Damage Roads Patrol): Aplikasi Pendeteksi Jalan Rusak Memanfaatkan Accelerometer pada Smartphone
}

\author{
Rudi Hartono ${ }^{1}$, Yudi Wibisono ${ }^{2}$, Rosa Ariani Sukamto ${ }^{3}$ \\ Program Studi Ilmu Komputer, \\ Fakultas Pendidikan Matematika dan Ilmu Pengetahuan Alam, \\ Universitas Pendidikan Indonesia \\ Jl. Setiabudi No. 229 Bandung 40154 Jawa Barat - Indonesia \\ ${ }^{1}$ rudi.hartono@student.upi.edu \\ ${ }^{2}$ yudi@upi.edu \\ ${ }^{3}$ rosa.ariani@upi.edu
}

\begin{abstract}
Abstrak-Kerusakan jalan merupakan permasalahan serius yang dihadapi baik oleh pemerintah ataupun masyarakat. Untuk membantu penyelesaian masalah tersebut dikembangkan aplikasi yang bertujuan untuk melaporkan kerusakan jalan secara otomatis dengan memanfaatkan akselerometer dan GPS pada smartphone. Aplikasi pendeteksi jalan rusak memanfaatkan akselerometer dan GPS untuk mengumpulkan data jalan, kemudian menganalisis data yang terkumpul untuk mendapatkan informasi titik-titik kerusakan. Algoritma Pothole Patrol diimplementasikan untuk mengenali berbagai kerusakan jalan. Percobaan yang dilakukan menggunakan mobil sejauh $50 \mathrm{~km}$ di jalanan Bandung yang terdiri dari berbagai kerusakan jalan seperti: lubang, retak, bergelombang dan deformasi, serta berbagai bagian jalan seperti polisi tidur, sambungan siar muai, dan persimpangan jalan. Hasil pengujian menghasilkan nilai presisi $88 \%$, recall 92\%, dan F-Measure 0,92.
\end{abstract}

Kata kunci: Jalan rusak, smartphone, accelerometer, GPS, Pothole Patrol.

\section{PENDAHULUAN}

Jalan merupakan prasarana transportasi darat yang mempunyai peranan sangat penting dalam mendukung bidang ekonomi, sosial dan budaya serta berbagai aspek kehidupan masyarakat lainnya. Berbagai aktivitas masyarakat dipengaruhi oleh kondisi jalan. Jalan yang memiliki kondisi baik akan memberikan kenyamanan dan memperlancar aktivitas perekonomian suatu daerah.

Tingginya aktivitas masyarakat akan berbanding lurus dengan beban lalu lintas yang menjadi tinggi. Beban lalu lintas yang tinggi akan meningkatkan beban jalan, dan menyebabkan kerusakan perkerasan jalan. Kerusakan perkerasan jalan adalah kerusakan yang terjadi pada permukaan jalan yang mengakibatkan menurunnya fungsi jalan.

Terjadinya kerusakan perkerasan jalan banyak mengakibatkan masalah dan gangguan yang terjadi. Berbagai gangguan baik terhadap pengguna maupun kepada pemerintah selaku penyelenggara jalan. Kemacetan, keselamatan, biaya

'http://wartakota.tribunnews.com/2013/11/23/kerugian-akibat-kecelakaan-di-jakarta-utara-capai-rp-18miliar\#

${ }^{2}$ http://www.merdeka.com/uang/kementerian-pu-ada-3338-lubang-di-sepanjang-jalur-pantura.html ${ }^{3}$ http://www.jpnn.com/read/2014/07/30/248957/Akibat-Jalan-Rusak,-Macet-Hingga-Dua-Kilomete perbaikan dan biaya ganti rugi kecelakaan merupakan contoh nyata dampak kerusakan jalan yang selalu dihadapi selama ini.

Berikut ini adalah beberapa data terkait dampak kerusakan jalan dari beberapa portal berita elektronik nasional:

1. Satuan Lalu Lintas Polres Jakarta Utara melaporkan kecelakaan lalu lintas dari Januari-Oktober 2012 terjadi akibat jalan berlubang dan kerusakan jalan lainnya. Dari kecelakaan tersebut dapat ditaksir kerugian mencapai 1,8 miliar rupiah ${ }^{1}$.

2. Kementrian PU mencatat ada 3.338 lubang disepanjang jalur pantura yang ditaksir akan menghabiskan 300 miliar sampai 400 milliar untuk memperbaiki kerusakan tersebut ${ }^{2}$.

3. Kemacetan yang diakibatkan jalan rusak mencapai $2 \mathrm{~km}$, terjadi di daerah Cikarang Barat ${ }^{3}$.

Pengawasan, perbaikan dan pemeliharaan jalan yang harus dilakukan secara efektif oleh pemerintah agar jalan tetap dalam kondisi baik dan memberikan kenyamanan kepada pengguna.

\section{PEnElitian TERKait}

Ada beberapa metode pemantauan jalan yang dapat dilakukan selain dengan metode manual. Secara umum sistem pemantauan kondisi jalan dibedakan menjadi tiga jenis metode yaitu metode gambar dua dimensi, metode getaran, dan metode 3D reconstruction [1].

Di Indonesia, penelitian penilaian kondisi jalan dilakukan salah dengan menggunakan metode gambar dua dimensi, dengan memanfaatkan metode template macthing[2]. Template matching adalah metode image processing yang membandingkan kecocokan gambar baru dengan gambar pembanding. Metode ini dapat menilai kondisi kerusakan jalan dengan akurasi 75\% [2]. Namun kekurangan dari teknik ini adalah pengambilan gambar dilakukan secara manual, sehingga penilaian kondisi jalan akan memerlukan waktu yang lama, meskipun hasil yang dicapai cukup baik. Sehingga informasi kerusakan tersebut akan kurang bermanfaat bagi pengendara secara cepat. 
Sistem pemantauan yang dilakukan di Amerika Serikat, melalui sebuah sistem yang dikembangkan bernama Pothole Patrol. Pothole patrol merupakan sistem pamantauan jalan berlubang secara otomatis memanfaatkan metode getaran yang didapat dari akselerometer sebagai sensor getaran [3]. Tujuan dari sistem ini untuk menurunkan tingkat kecelakaan dan klaim asuransi akibat kerusakan jalan yang tinggi di Amerika. Sistem diuji di area kota Boston dengan jarak mencapai \pm 1000 KM. Sistem ini menghasilkan akurasi 92\% dalam mendeteksi jalan rusak. Sistem ini juga dilengkapi dengan data lokasi yang bersumber dari sensor GPS, sehingga setiap lokasi yang berhasil dideteksi oleh sistem akan diketahui titik lokasinya secara jelas. Sistem ini dapat membedakan berbagai bagian jalan yang bukan merupakan jalan rusak, seperti: sambungan siar muai (expansion joint), dan persimpangan jalan kereta api (rail crossing). Namun sistem ini memanfaatkan dua alat sensor untuk menggumpulkan data, yaitu akselerometer sebagai sensor untuk data getaran dan GPS Tracker yang membutuhkan biaya yang mahal dan kurang praktis.

Selain itu sistem pemantauan jalan secara otomatis juga dilakukan di Sri Lanka yang menggunakan akselerometer sebagai alat ukur getaran dan PDA sebagai alat untuk mendapatkan data lokasi[4]. Sistem ini dibangun untuk mengatasi permasalahan pelaporan jalan berlubang. Namun kekurangan pada sistem ini adalah lokasi kerusakan jalan yang sulit dikenali, karena alat yang digunakan untuk mengumpulkan data getaran yang mengindikasikan jalan rusak dan data lokasi yang berbeda, sehingga terdapat jarak penggambilan data yang tidak sama, serta kekurangan juga terdapat pada algoritma yang digunakan untuk mendeteksi jalan rusak. Algoritma yang digunakan pada sistem ini hanya menggunakan satu sumbu akselerometer yaitu sumbu vertikal (Z). Sehingga sistem tidak mampu mengenali beberapa bagian jalan yang bukan merupakan jalan rusak seperti: polisi tidur, persimpangan jalan, dan sambungan siar muai.

\section{A. Algoritma Sistem Deteksi Jalan Berlubang}

Pathole Patrol [1] mengembangkan sistem filter untuk mengenali jalan berlubang. Proses filter diterapkan pada data akselerometer dan GPS. Berikut adalah penjelasan detail proses filter yang diterapkan[1].

a. Kecepatan: tahap pertama melalui seleksi berdasarkan kecepatan, jika kecepatan nol atau mobil berjalan sangat pelan, maka data tersebut dibuang. Modul ini akan membuang kejadian seperti berhenti dan memasuki area trotoar.

b. High-pass filter: High-pass filter akan menghapus sinyal dengan frekuensi rendah pada percepatan setiap sumbu $x$ dan z yang masuk. Beberapa kejadian yang menghasilkan frekuensi rendah diantaranya, tarikan gas, tikungan, belokan, pengereman dan beberapa perubahan kecil yang disebabkan orientasi perangkat (smartphone).

c. Puncak sumbu $\mathbf{Z}(\boldsymbol{t} z)$ : menentukan nilai batas sumbu $Z$ yang akan menjadi acuan identifikasi pothole. jika data yang masuk lebih besar dari besar dari pada $t z$ maka sistem secara otomatis akan membuang data tersebut. Dengan beberapa percobaan maka didapatlah angka 0.2 sebagai nilai dari tz yang menghasilkan kecocokan deteksi kerusakan jalan menggunakan sistem

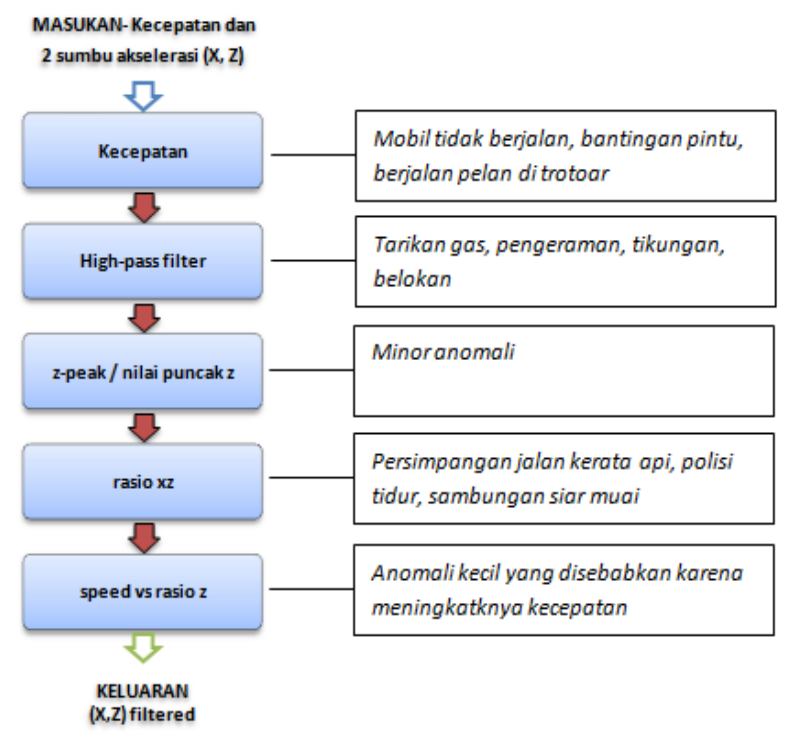

Gambar 1 Pendeteksian lubang jalan yang terdiri dari lima modul filter untuk memisahkan anomali jalan yang bukan jalan berlubang (pothole) [3]

d. Perbandingan antara sumbu $\mathbf{X}$ dan $\mathbf{Z}(t x)$ : filter yang kedua menggunakan perbandiangan antara dua sumbu $\mathrm{X}$ dan $\mathrm{Z}$ yaitu menentukan nilai ( $t x$ ) yang menjadi batas identifikasi jenis anomali yang benar jalan rusak dengan anomali jenis lain yang bukan merupakan kerusakan jalan seperti polisi tidur, sambungan suar muai, dan persimpangan jalan raya. Untuk setiap data $X$ dan $Z$ yang masuk, jika $\mathrm{X}$ dibagi dengan $\mathrm{Z}$ kurang dari $t x$, maka data tersebut dibuang atau dapat ditulis buang semua data jika $\frac{x}{Z}<t x$

e. Kecepatan dan rasio z: tahap filter yang terakhir identifikasi kerusakan jalan dengan membandingkan data kecepatan dengan sumbu Z. Karena tingginya nilai z yang dihasilkan berbanding lurus dengan laju kendaraan. Jika kendaraan melaju dengan kecepatan tinggi, maka nilai $\mathrm{Z}$ yang dihasilkan akan semakin tinggi. Jadi untuk membuang data dengan nilai $\mathrm{Z}$ yang tinggi karena efek kecepatan dapat diatasi menggunakan rumus $Z<$ ts $\times$ speed.

\section{B. Algoritma Sistem Deteksi Jalan Berlubang}

Pelatihan sistem dilakukan untuk mencari kombinasi terbaik untuk setiap parameter pengukuran $t=\left\{t_{z}, t_{x}, t_{s}\right\}$, sehingga menghasilkan akurasi yang tinggi pada sistem pendeteksi jalan rusak yang dikembangkan[3]. Masing-masing nilai $t$ dicari pada range angka tertentu untuk kemudian dilakukan proses deteksi untuk menghasilkan skor dari setiap $t$ yang diuji. Skor tertinggi yang dihasilkan masing-masing nilai $\mathrm{t}$ diambil sebagai kombinasi terbaik dan dijadikan sebagai parameter pengukuran. Persamaan untuk menghitung skor:

dimana:

$$
s(t)=\text { corr }- \text { incorr }{ }^{2}
$$

$s=$ skor

$t=$ parameter pengukuran $\left\{t_{z}, t_{x}, t_{s}\right\}$ 
corr $=$ total jalan rusak yang berhasil terdeteksi benar incorr $=$ total jalan rusak yang salah didideteksi

\section{ARSITEKTUR SISTEM DETEKSI JALAN RUSAK DAMROPA}

Pada bagian ini akan dibahas tentang arsitektur sistem yang dikembangkan untuk mengenali berbagai jenis kerusakan jalan. Lihat gambar 2.1 yang merupakan ilustrasi sistem pendeteksi jalan rusak yang dinamai dengan Damropa (Damage roads patrol).

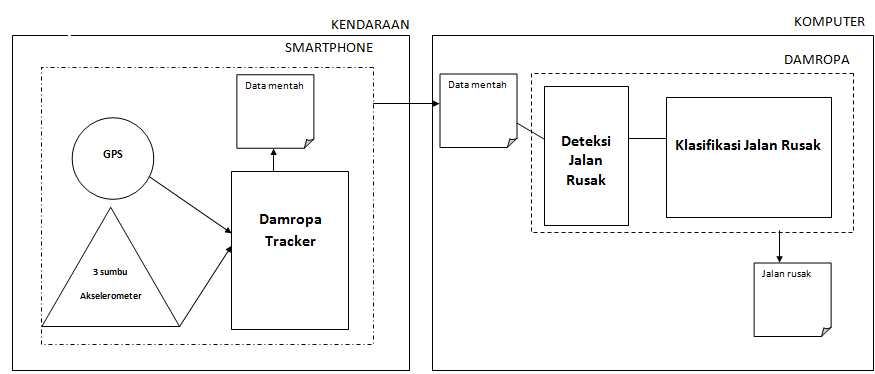

Gambar 2 arsitektur dan alur sistem pendeteksi jalan rusak dari pengumpulan data hingga menghasilkan data jalan rusak

Damropa terdiri dari smartphone yang dipasang pada mobil, dan komputer, seperti yang diilustrasikan gambar 2 data direkam menggukan aplikasi Damropa Tracker untuk mengumpulkan data akselerometer dan GPS. Dimana masingmasing memberikan data yang berbeda.

Akselerometer yang terdiri dari tiga sumbu akselerasi yaitu Z, Y, dan Z. Sedangkan GPS menghasilkan data lokasi (latitude dan longitude), arah, dan kecepatan.

\section{HASIL PERCOBAAN}

\section{A. Pengumpulan Data}

Pengumpulan data dilakukan menggunakan mobil di wilayah Kota Bandung, bergerak dengan kecepatan rata-rata 32 $\mathrm{km} / \mathrm{jam}$ dan dibeberapa area dipercepat menjadi $36 \mathrm{~km} / \mathrm{jam}$, berkendara selama 1,45 jam sehingga dapat dihitung bahwa jarak tempuh $50 \mathrm{~km}$.

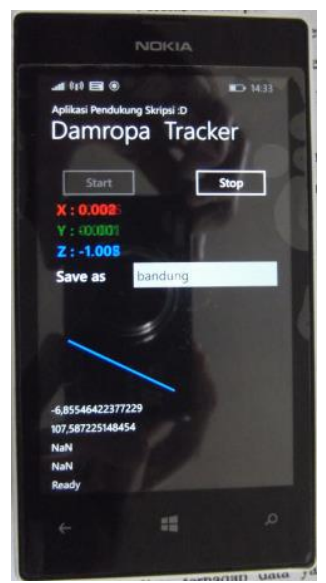

Gambar 3 screenshot aplikasi perekam data akselerometer dan GPS

\section{B. Proses Deteksi Jalan Rusak}

Proses deteksi kerusakan jalan dilakukan secara otomatis menggunakan perangkat lunak yang kembangkan yang dibandingkan dengan kerusakan jalan yang dicatat secara manual. Proses deteksi terdiri dari dua tahap yaitu tahap filter dan tahap labeling dan klasifikasi berdasarkan lokasi GPS.

Berikut adalah hasil filter yang dilakukan secara otomatis oleh sistem.

a. Kecepatan: minimum kecepatan yang akan dideteksi oleh sistem adalah $5 \mathrm{~km} / \mathrm{jam}$ sehingga semua record data dengan kecepatan dibawah $5 \mathrm{~km} / \mathrm{jam}$ akan dibuang.

b. Efek High-pass filter: efek yang dihasilkan adalah menghapus nilai akselerasi yang dihasilkan karena tarikan gas, belokan, putaran, pengereman, dan perubahan orientasi smartphone.

c. Puncak sumbu $\mathbf{Z}(\boldsymbol{t z})$ : dengan beberapa percobaan maka didapatlah angka 0.2 sebagai nilai dari $t z$ yang menghasilkan tingkat kesesuaian deteksi anomali jalan paling tinggi. Anomali yang terdeteksi cukup beragam seperti, sambungan siar muai, polisi tidur, persimpangan jalan, jalan berlubang, retak, dan jenis anomali jalinnya.

d. Perbandingan antara sumbu $\mathbf{X}$ dan $\mathbf{Z}(\boldsymbol{t} \boldsymbol{x})$ : filter yang kedua menggunakan perbandiangan antara dua sumbu $X$ dan $\mathrm{Z}$ yaitu menentukan nilai $(t x)$ yang menjadi batas identifikasi jenis anomali yang benar jalan rusak dengan anomali jenis lain yang bukan merupakan kerusakan jalan seperti polisi tidur, sambungan siar muai (komponen jalan dan jembatan yang berfungsi untuk menyambungkan bangunan), dan persimpangan jalan raya. Untuk setiap data $\mathrm{X}$ dan $\mathrm{Z}$ yang masuk, jika $\mathrm{X}$ dibagi dengan $\mathrm{Z}$ kurang dari $t x$, maka data tersebut dibuang atau dapat ditulis buang semua data jika $\frac{X}{Z}<t x$. Pada percobaan ini menggunakan $t x=0,257$, titik yang berhasil terdeteksi adalah 135 anomali.

e. Kecepatan dan rasio $\mathbf{z}$ : tahap filter yang terakhir identifikasi kerusakan jalan dengan membandingkan data kecepatan dengan sumbu Z. Karena tingginya nilai z yang dihasilkan berbanding lurus dengan laju kendaraan. Jika kendaraan melaju dengan kecepatan tinggi, maka nilai $\mathrm{Z}$ yang dihasilkan akan semakin tinggi. Jadi untuk membuang data dengan nilai $\mathrm{Z}$ yang tinggi karena efek kecepatan dapat diatasi menggunakan rumus $Z<$ ts $\times$ speed. Percobaan ini menambahkan $t s$ sebesar 0,008 sehingga menghasilkan 102 titik kerusakan yang berhasil dideteksi.

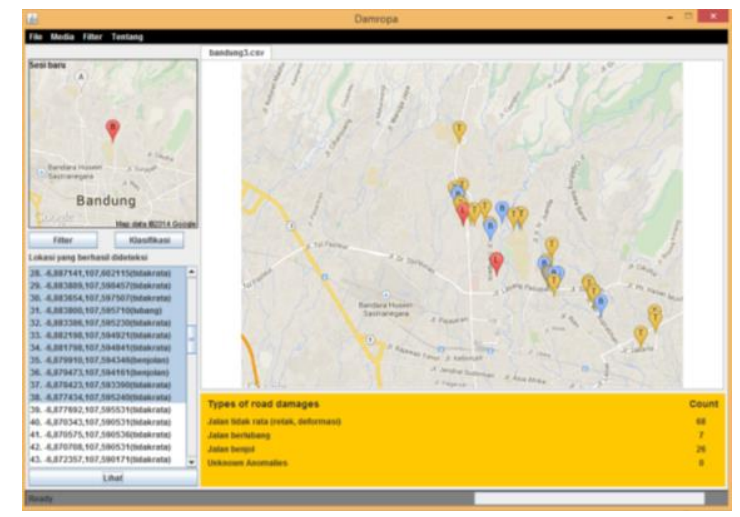

Gambar 4 Screenshot aplikasi saat menampilkan lokasi jalan rusak yang berhasil diidentifikasi oleh sistem menggunakan $t z, t x$, dan $t s$ 
Gambar 4 memperlihatkan 102 titik yang berhasil dikenali sebagai jalan rusak yang akan dilanjutkan pada tahap deteksi jalan rusak. Tahap deteksi jalan rusak adalah pemberian label pada data sebagai jalan berlubang atau jalan dengan kondisi tidak rata. Dan yang terakhir adalah proses penggabungan hasil deteksi berdasarkan informasi yang didapatkan dari GPS.

Berikut adalah algoritma yang digunakan untuk proses penggabungan lokasi deteksi.

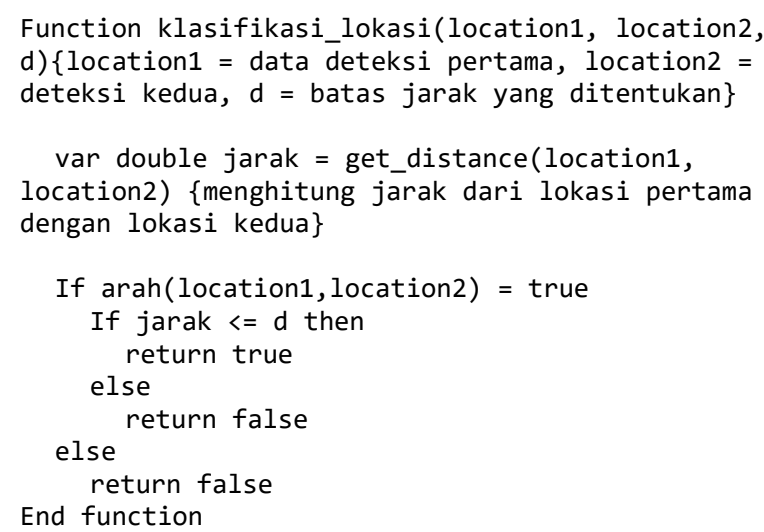

\section{Menghitung Presisi, Recall dan F-Measure}

Untuk mengukur tingkat kemampuan sistem dalam mendeteksi kerusakan jalan, diperlukan perhitungan melalui presisi, recall, dan F-measure[5]. Pada percobaan yang telah dilakukan terdapat 1124 total lokasi yang harus dideteksi dimana dari 1124, 100 titik yang merupakan benar jalan rusak. Berikut adalah perhitungan kemampuan sistem terhadap data yang dideteksinya.

1. Kemampuan deteksi sistem berdasarkan $t z=0,2$, menghasilkan total deteksi sebanyak 276 titik.

Tabel 1 Matrik deteksi sistem terhadap kerusakan jalan dengan $t z=0,2$

\begin{tabular}{|l|l|l|}
\cline { 2 - 3 } \multicolumn{1}{c|}{} & Benar & Salah \\
\hline Jalan rusak & 100 & 176 \\
\hline $\begin{array}{l}\text { Bukan jalan } \\
\text { rusak }\end{array}$ & 0 & 848 \\
\hline
\end{tabular}

Hasil tersebut menunjukan bahwa sistem belum stabil untuk mengenali jalan rusak. Dengan nilai presisi 36,2\% dan recall $100 \%$, sehingga F-score keseimbangan pendeteksian masih 0,52.

2. Kemampuan deteksi dengan menambahkan parameter $t x$ $=0,257$, menghasilkan total deteksi sebanyak 135 titik.

Tabel 2 Matrik deteksi sistem terhadap kerusakan jalan dengan $t z=0,2$,

\begin{tabular}{|l|l|l|}
\multicolumn{1}{c|}{$t x=0,257$} & Salah \\
\cline { 2 - 3 } \multicolumn{1}{c|}{ Benar } & 39 \\
\hline Jalan rusak & 95 & 848 \\
\hline $\begin{array}{l}\text { Bukan jalan } \\
\text { rusak }\end{array}$ & 5 & \\
\hline
\end{tabular}

Hasil di atas menunjukan bahwa sistem belum stabil untuk mengenali jalan rusak. Dengan nilai presisi $71 \%$ dan recall 95\%, dengan $F$-Score kurang dari 0,5.
3. Kemampuan deteksi dengan menambahkan parameter $t x$ $=0,008$, menghasilkan total deteksi sebanyak 102 titik.

Tabel 3 Matrik deteksi sistem terhadap kerusakan jalan dengan $t z=0,2, t x=0,257, t s=0,008$

\begin{tabular}{|l|l|l|}
\cline { 2 - 3 } \multicolumn{1}{c|}{} & Benar & Salah \\
\hline Jalan rusak & 90 & 12 \\
\hline $\begin{array}{l}\text { Bukan jalan } \\
\text { rusak }\end{array}$ & 10 & 848 \\
\hline
\end{tabular}

Hasil di atas menunjukan bahwa sistem sudah stabil untuk mengenali jalan rusak. Dengan nilai presisi $88 \%$ dan recall $95 \%$, menghasilkan $F$-score 0,92 yang menandakan bahwa sistem memiliki akurasi yang tinggi.

Dapat diambil kesimpulan bahwa agar sistem memiliki kinerja yang baik dalam mendeteksi jalan rusak harus menggunakan ketiga parameter filter yaitu: $t z, t x$, dan $t s$. Karena ketiga parameter tersebut dapat mendeteksi bagian yang bukan merupakan jalan rusak, seperti polisi tidur, sambungan siar muai, persimpangan jalan, dan lain-lain. Sehingga kejadian yang lolos dari ketiga filter tersebut dapat dipastikan sebagai jalan rusak dengan persentase keberhasilan tinggi.

\section{ANALISIS}

Pada percobaan di atas menghasilkan beberapa kesalahan deteksi, kesalah deteksi setelah data mengalami filter menjadi fokus analisis masalah tersebut. Berikut adalah beberapa permasalahan yang timbul pada deteksi yang dilakukan oleh sistem perangkat lunak yang dikembangkan.

Dari ketiga permasalah yang terjadi, berikut ini adalah analisis terhadap masing-masing permasalahan tersebut.

1. Lokasi yang dihasilkan GPS kadang tidaktidak akurat. Permasalah ini terjadi pada lokasi pada kordinat (-6.87842317856848, 107.593389619142). Beberapa permasalahan juga terjadi pada titik-titik lain

2. Permasalahan yang kedua adalah beberapa titik yang bukan merupakan jalan rusak yang seharusnya tidak dikenali oleh sistem ternyata dideteksi sebagai jalan rusak. Terjadi pada beberapa titik dengan kondisi jalan: sambungan siar muai, polisi tidur, tanjakan singkat, dan persimpangan jalan (gambar 5). Permasalahan ini terjadi karena polisi tidur yang dilewati memiliki ukuran yang kecil lihat (gambar 5a), sehingga apabila dilewati dengan cepat akan berdampak pada getaran yang cukup signifikan pada kendaraan. Masalah lain beberapa persimpangan jalan memiliki pertemuan antara satu dengan yang lain yang tidak begitu sempurna.

3. Kasus lain yang unik disebut dengan tanjakan singkat. Pembacaan akselerometer menunjukan bahwa ini merupakan salah satu kelainan jalan yang dikenali sebagai jalan rusak, karena kasus pembacaannya berbeda dengan beberapa bagian jalan seperti polisi tidur dan sambungan siar muai. Pada kenyataannya bagian tersebut apabila dilewati dengan kecepatan tinggi akan menyebabkan loncatan yang berbahaya bagi pengendara.

4. Kerusakan jalan yang tidak dapat dikenali oleh sistem, ini terjadi pada beberapa titik kerusakan jalan yang diprediksi 
akan dapat dikenali. Seperti yang terjadi pada titik di sepanjang Jalan Ahmad Yani, yang memiliki permukaan jalan tidak rata dan banyak permasalahan jalan berjenis retak. Namun titik-titik tersebut ternyata tidak dapat dideteksi oleh sistem. Setelah dilakukan analisis pada pembacaan akselerasinya, walaupun nilai akselerometer tinggi namun akhirnya terbuang karena faktor $t s$. Itu terjadi karena kenaikan $\mathrm{Z}$ yang tinggi diiringi dengan laju kendaraan yang meningkat sehingga data tersebut dibuang karena rasio antara kecepatan dan sumbu $\mathrm{Z}$ yang diuji kurang dari ts yang telah ditentukan.

5. Perilaku pengemudi juga merupakan permasalahan yang dihadapi di lapangan. Rem mendadak, tarikan gas, berhenti di trotoar secara tiba-tiba dan kebut-kebutan merupakan hal yang dapat mempengaruhi pembacaan akselerometer, sehingga akan berakibat pada akurasi deteksi yang memburuk.

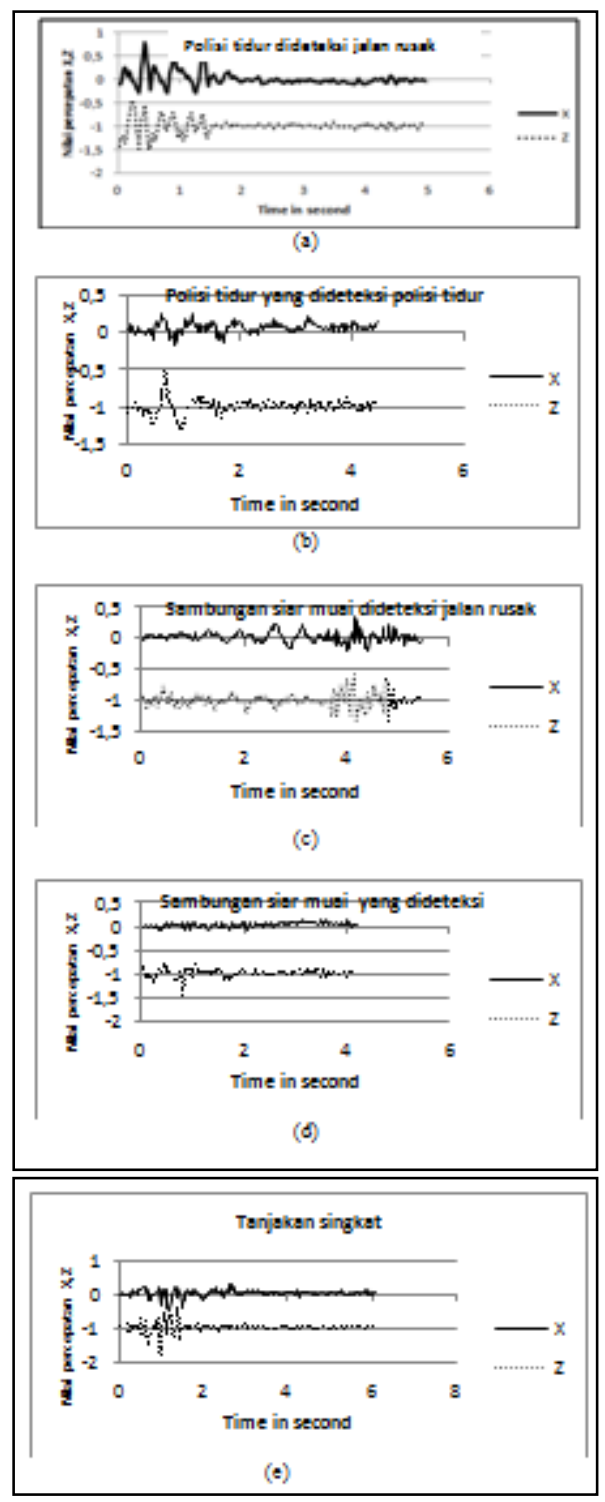

Gambar 5 Grafik akselerasi yang dihasilkan akselerometer terhadap berbagai jenis bagian jalan ( (a) polisi tidur yang dideteksi sebagai jalan rusak, (b) polisi tidur yang dideteksi sebagai polisi tidur, (c) sambungan siar muai yang dideteksi sebagai jalan rusak, (d) sambungan siar muai yang dideteksi sebagai sambungan siar muai, dan (e) tanjakan singkat)
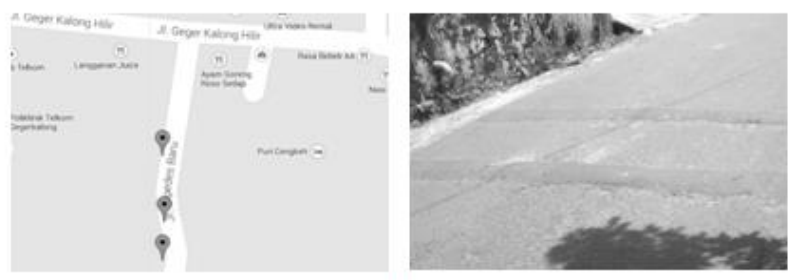

(a)
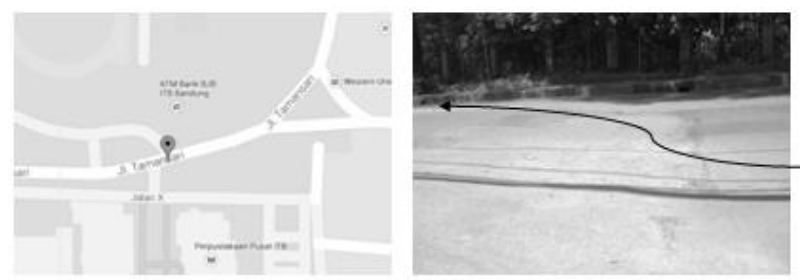

(b)
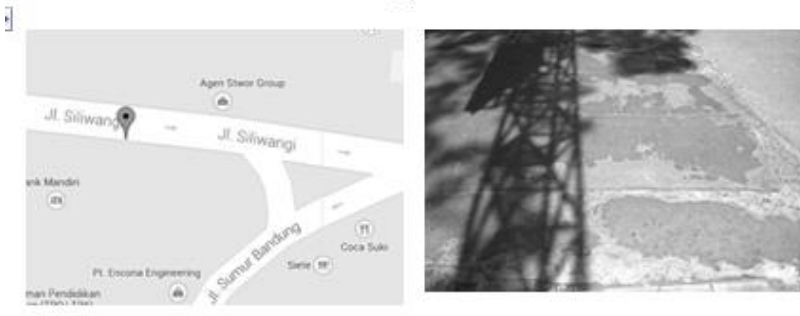

(c)

Gambar 6 Kesalahan identifikasi sistem pada titik-titik dimana (a) adalah tiga polisi tidur, (b) tanjakan singkat, dan (c) sambungan siar muai atau sambungan jalan

\section{PENUTUP}

Pemantauan kerusakan jalan secara otomatis menggunakan akselerometer dan GPS pada smartphone merupakan hal yang sangat mungkin dilakukan. Sensitifitas sensor akselerometer memberikan kemudahan untuk membedakan sinyal getar yang ditimbulkan karena jalan rusak dengan sinyal getar karena jenis atau bagian jalan lainnya.

Algoritma filter yang dikembangkan dapat membedakan berbagai jenis bagian jalan yang bukan merupakan jalan rusak seperti: polisi tidur, sambungan siar muai, dan persimpangan jalan.

Didukung dengan sensor GPS smartphone yang memberikan akurasi pelaporan lokasi cukup baik $( \pm 10$ meter $)$, memudahkan pengguna untuk mengetahui lokasi kerusakan yang dilaporkan melalui peta digital yang disediakan oleh Google Map Services. 


\section{DAFTAR PUSTAKA}

[1] Kim, Taehyeong dan Ryu, Seung-ki. Review and Analysis of Pothole Detections Methods. Journal of Emerging Trends in Computing and Reformation Sciences. Volume 5 , No. 8. 2014.

[2] Daru, Setiyono C. Sistem Deteksi Kerusakan Permukaan Jalan Raya dengan Metode Template Matching [Online]. Tersedia: http://unmermadiun.ac.id/repository_jurnal_penelitian/Jurnal\%20Agrite $\mathrm{k} / \mathrm{Jurnal} \% 20$ Agri-

tek\%202014/September/10.\%20Setyo_Daru\%20hal\%20105-

111.pdf.2014.

[3] Eriksson, Jacob, dkk. The Pothole Patrol: Using a Mobile Sensor Network for Road Surface Monitoring. [Online]. Tersedia: http://www.ece.northwestern.edu/ peters/references/PatholePatrol.pdf. 2008.

[4] D., Girisha De Silva, S., Ravin Perera, M., Nayanajith. Automated Pothole Detection System. University of Colombo School of Computing. Sri Lanka: Colombo. 2008.

[5] Perhituangan Performance melalui Recall, Presisi, dan F-Measure. Slide Presentasi Universitas The George Washington[Online]. Tersedia:

http://www.seas.gwu.edu/ bell/csci243/lectures/performance.pdf. 